\title{
Ocular adnexal lymphoma-comparison of MALT lymphoma with other histological types
}

\author{
Mark Cahill, Colma Barnes, Paul Moriarty, Peter Daly, Susan Kennedy
}

\begin{abstract}
Aims-To correlate histological features of ocular adnexal lymphoma using the revised European American lymphoma classification (REAL), with stage of disease at presentation, treatment modalities, and patient outcome. MALT lymphoma defines an extranodal marginal zone B cell lymphoma as outlined in the REAL classification. Comparison groups of patients included those with primary ocular adnexal MALT lymphoma versus primary ocular adnexal lymphomas of other types, MALT lymphoma versus non-MALT lymphomas (primary and secondary), and primary ocular adnexal lymphoma (MALT lymphomas and other types) versus secondary ocular adnexal lymphomas.
\end{abstract}

Methods-A retrospective review of the National Ophthalmic Pathology Laboratory records identified 20 cases of ocular adnexal lymphoma over a 10 year period which were reclassified using appropriate immunohistochemical stains. Patients' medical records were examined for data including stage of the disease at presentation, mode of treatment, and patient outcome.

Results-Among the 20 cases identified 14 had primary ocular adnexal lymphomas. 10 of the primary lymphomas had histological features of MALT lymphoma. One case was a primary ocular adnexal $T$ cell lymphoma, one a follicular centre, follicular $B$ cell lymphoma, and two were large cell B cell lymphomas. Six cases had systemic disease, four large $B$ cell, one follicular centre, follicular B cell, and one mantle cell. A significantly higher proportion of patients with MALT lymphomas had early disease $(p=0.005)$, initially required local treatment $(p=0.005)$ and were alive at last follow up $(p=0.001)$ than those without. Two patients with MALT lymphoma had recurrence of lymphoma which responded to further treatment. Conclusions-Patients with primary ocular adnexal MALT lymphomas present with localised disease requiring local treatment and have a better outcome compared with patients with other types. As a small percentage of these tumours recur, patients should be followed up indefinitely.

(Br F Ophthalmol 1999;83:742-747)

Ocular adnexal lymphoid tumours may involve the eyelids, conjunctiva, orbital connective tis- sue, or lacrimal structures. Pathological diagnosis is based on routine light microscopy supported by immunohistochemical staining (or molecular genetic analysis) to identify lineage. ${ }^{1}$ The presence of light chain restriction (cells expressing only one immunoglobulin light chain) is characteristic of B cell lymphomas, but differentiation between benign and malignant lesions may be extremely difficult on small biopsies. ${ }^{1}$ The majority of ocular adnexal lymphomas are non-Hodgkin's B cell lymphomas and by definition are extranodal lymphomas. Older classifications of lymphomas, including the working formulation, ${ }^{2}$ and the Kiel classification, ${ }^{3}$ referred to lymphomas originating in lymph node sites but did not recognise extranodal lymphomas as distinct clinical entities resulting in inappropriate classification of some tumours. Lymphomas arising at extranodal sites are relatively common accounting for between $24 \%$ and $48 \%$ of lymphomas and besides ocular adnexal lymphomas also include peripheral $\mathrm{T}$ cell lymphomas such as mycosis fungoides. $^{45}$

The new revised European American lymphoma classification (REAL) of lymphoid malignancy first proposed by the International Lymphoma Study Group differs from older classifications in recognising these new entities and is not only based on classic histological criteria but also clinical, immunohistochemical, and molecular genetic data. ${ }^{6}$ The REAL classification in many instances condensed a number of terms used in the previous classifications into one group with or without a small number of provisional subgroups as highlighted in Table 1. Included in the extranodal group of lymphomas are marginal zone B cell lymphoma of MALT (mucosal associated lymphoid tissue) type or MALT lymphomas.

MALT lymphomas are characterised by cellular heterogeneity including small lymphocytes with moderate amount of pale cytoplasm and typically irregular or cleaved nuclei (centrocyte-like lymphocytes) and small round lymphocytes. Monocytoid B cells, plasma cells, and the occasional large cell are also seen. The diagnosis of MALT lymphomas can be difficult and histologically in the early stages they exist as an infiltrate between pre-existing reactive follicles which they can overrun (follicular colonisation). Similarly, lymphoma cells may infiltrate overlying mucosal surfaces with subsequent inclusion of epithelial islands (lymphoepithelial lesions). MALT lymphomas may be acquired secondary to autoimmune disease or infection at a given site providing the substrate for lymphoma development. These lymphomas were first
Accepted for publication 18 December 1998 
Table 1 Comparison of selected subtypes in three classifications (modified from Harris et al')

\begin{tabular}{|c|c|c|}
\hline REAL classification ${ }^{6}$ & Working formulation ${ }^{3}$ & Updated Kiel classification ${ }^{2}$ \\
\hline $\begin{array}{l}\text { Extranodal marginal zone B cell lymphoma (low } \\
\text { grade B cell lymphoma of MALT type) }\end{array}$ & $\begin{array}{l}\text { Small lymphocytic } \\
\text { Diffuse, small cleaved cell } \\
\text { Diffuse, mixed small and large cell }\end{array}$ & No equivalent \\
\hline Lymphoplasmacytoid lymphoma & $\begin{array}{l}\text { Small lymphocytic plasmacytoid } \\
\text { Diffuse, mixed small and large cell }\end{array}$ & Lymphoplasmacytic immunocytoma \\
\hline Follicular centre lymphoma, diffuse, small cell & Diffuse, small cleaved cell & Centroblastic-centrocytic, diffuse \\
\hline Follicular centre lymphoma, follicular & $\begin{array}{l}\text { Follicular, predominantly small, large, or mixed cells } \\
\text { Follicular, mixed small and large cells } \\
\text { Follicular, predominantly large cell }\end{array}$ & Centroblastic-centrocytic, follicular \\
\hline Diffuse large B cell lymphoma & $\begin{array}{l}\text { Diffuse, large cell } \\
\text { Large cell immunoblastic } \\
\text { Diffuse, mixed small and large cell }\end{array}$ & Centroblastic or B immunoblastic \\
\hline Mantle cell lymphoma & $\begin{array}{l}\text { Diffuse, small cleaved cell } \\
\text { Small lymphocytic } \\
\text { Follicular, small cleaved cell, } \\
\text { Diffuse, mixed small and large cell } \\
\text { Diffuse, large cleaved cell }\end{array}$ & $\begin{array}{l}\text { Centrocytic } \\
\text { Centroblastic, centrocytoid subtype }\end{array}$ \\
\hline Peripheral $\mathrm{T}$ cell lymphomas, unspecified & Diffuse, mixed small and large cell & Pleomorphic, medium sized and large $\mathrm{T}$ cell \\
\hline
\end{tabular}

*When REAL category is equivalent to more than one working formulation or updated Kiel category, italicised category comprises the majority of cases.

described in the mucosal tissue of the stomach $^{7-9}$ and typical histological changes have also been documented in lymphomas of lung, salivary gland, thyroid, and conjunctiva. ${ }^{10-14}$ As the criteria for diagnosis of MALT lymphomas have become more defined (partially because of the availability of suitable immunohistochemical stains), histologically similar primary tumours have been identified in non-mucosal sites (that is, tissues without an overlying epithelium) such as orbital soft tissue. ${ }^{15-17}$ MALT lymphomas are thought to have an indolent natural history and respond well to radiotherapy. ${ }^{17-19}$ They may recur, however, and the site of recurrence may be another typical MALT site. ${ }^{14-17}$

A number of previous studies have attempted to correlate pathological diagnosis with clinical outcome in both lymphoid hyperplasia and malignant lymphoma of ocular adnexal tissues, but these were carried out before the advent of the REAL classification. ${ }^{20-26}$ However, these studies do identify a subgroup of lymphomas of small, well differentiated lymphocytes that had an indolent course. A recent clinicopathological study which focused on identifying MALT lymphomas found that, although a high proportion of ocular adnexal lymphomas had MALT characteristics, there was no significant difference between outcome in patients with MALT lymphomas and those with other histology. ${ }^{17}$ The current study was designed to correlate pathological diagnosis with clinical outcome of patients with ocular adnexal lymphoma in patients with a variety of histological subtypes.

\section{Materials and methods}

A retrospective clinicopathological study of ocular adnexal lymphoma referred on a nationwide basis to the National Ophthalmic Pathology Laboratory located in the Royal Victoria Eye and Ear Hospital over a 10 year period was undertaken. Using the National Ophthalmic Pathology register relevant cases were identified and the biopsy preparations were re-examined and reclassified according to the REAL classification. The reclassification was based on morphological features seen on routinely prepared slides of tissues fixed in formalin and embedded in paraffin wax. Immu- nophenotyping was carried out on fixed sections using the avidin-biotin peroxidase conjugate method ${ }^{27}$ and the Vector elite kit (Vector Laboratories, Burlingame, CA, USA). Normal tonsillar tissue served as a positive control for immunohistochemistry. Negative controls comprised of omission of the primary antibody and its replacement by serum on a duplicate section of the lymphoma to be tested. Immunohistochemical stains used included CD 20 (1:100, Dako Corporation, Santa Barbara, CA, USA) (to identify B lymphocytes), CD3 (1:50) (Dako Corporation), and CD45 RO (1:50, Dako Corporation) to identify T lymphocytes, CD21 (1:10, Dako Corporation), which demonstrates the dendritic skeleton of lymphoid follicles while Cytokeratin stain (undiluted, Becton Dickinson, San Jose, CA, USA) highlighted characteristic invasion of mucosal surfaces by lymphocytes. Selected cases were stained with CD 5 and CD 10 (1:100, 1;40 respectively, both from Novocastra, Newcastle upon Tyne) which can help differentiate between MALT lymphoma and other B cell neoplasms such as mantle cell lymphoma or follicular lymphomas. Rabbit antibodies to human immunoglobulin kappa and lambda light chains (1:300, 1:1000 respectively, Dako Corporation) were used to determine monoclonality. All the antibodies used were monoclonal with the exception of CD3 which was polyclonal. While the more recent cases had the immunohistochemistry done at the time of diagnosis, the majority of the cases required new samples to be cut from stored paraffin blocks for newer antibodies to be applied.

Disease was defined as primary ocular adnexal lymphoma provided no evidence of extraorbital disease was detected following a staging evaluation when a pathological diagnosis of lymphoma within the orbit was made. Staging evaluation included full blood count, differential white cell count, platelet count biochemical profile, bone marrow aspirate and biopsy, computed tomography (CT) scan (and/or magnetic resonance imaging) of the orbits along with CT examination of thorax and abdomen. Those patients with disease outside the orbits were classified as having dis- 

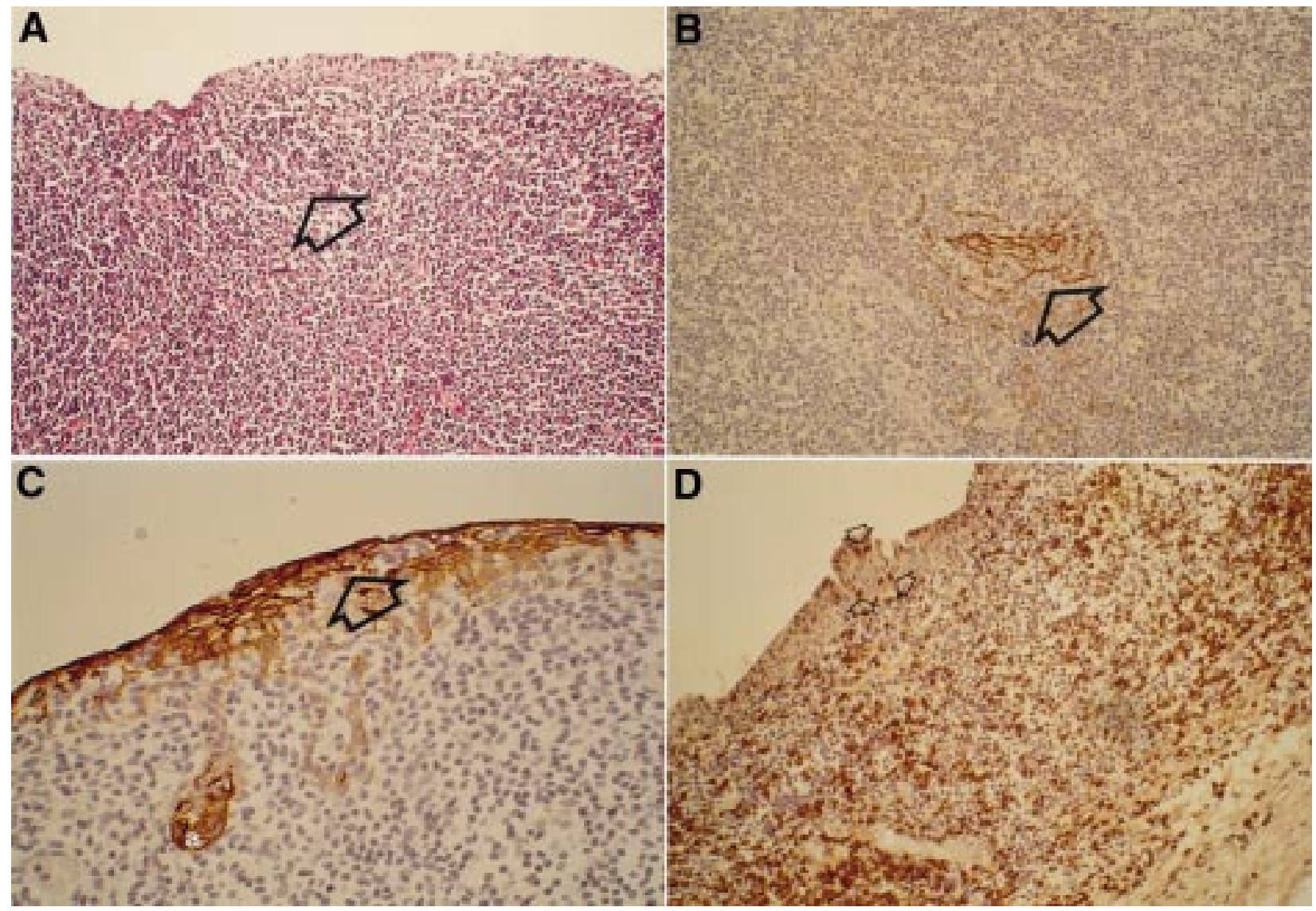

Figure 1 (A) Photomicrograph of conjunctival MALT lymphoma, demonstrating a monotonous infiltrate of small round and small cleaved lymphocytes. The remnant of a pre-existing germinal centre has been colonised by tumour cells (large arrow) (haematoxylin and eosin $\times 40$ ). (B) Photomicrograph of conjunctival MALT lymphoma, stained with the immunohistochemical stain for follicular dendritic cell delineates the skeleton of a pre-existing germinal centre (large arrow) $(C D 21 \times 40)$. (C) Photomicrograph of conjunctival MALT lymphoma, stained with immunohistochemical stain outlining a lymphoepithelial lesions (a) and highlighting lymphocytic invasion of the mucosal surface (large arrow) (cytokeratin $\times 400$ ). (D) Photomicrograph of conjunctival MALT lymphoma, stained with an immunohistochemical $T$ cell marker, demonstrating the typically high percentage of $T$ cells in these tumours. Many of the epithelial infiltrating lymphocytes are of T cell phenotype (small arrows) (CD $3 \times 40)$.

seminated lymphoma with orbital involvement labelled secondary ocular adnexal lymphoma.

Treatment modalities consisted of local excision alone, local excision with radiotherapy, radiotherapy alone, chemotherapy alone, or chemotherapy combined with radiotherapy. In terms of outcome patients were classified as alive without disease, alive with active disease, deceased secondary to lymphoma, or deceased secondary to other causes. Evaluation of disease stage, mode of treatment, and outcome required input from ophthalmologists and oncologists to whom patients had been referred for further evaluation and treatment.

Patients were categorised into three groups including those with primary ocular adnexal MALT lymphomas (group 1), patients with primary ocular adnexal lymphomas of other types (group 2), and patients with systemic lymphomas with orbital manifestations either at presentation or relapse (group 3). The significance of any differences between these groups with regard to stage of disease at presentation (when applicable), mode of initial treatment, and patient outcome was analysed using the Fisher exact test.

\section{Results}

Twenty cases of ocular adnexal lymphoma were identified from the records of the
National Ophthalmic Pathology Laboratory. Of these, 12 were male and eight were female (ratio 1.7:1) while the mean age of the patients was 62.2 years (median 62.0 years; range 35-82 years). The majority had primary lymphoma arising within the ocular adnexae (n $=14$ ), with the remainder being sites of disseminated lymphoma within ocular adnexal tissue $(n=6)$ (Table 2$)$.

\section{HISTOLOGICAL DIAGNOSIS}

The majority of patients in the primary lymphoma group had histological features of MALT lymphoma $(n=10)$, while one patient had a primary $\mathrm{T}$ cell lymphoma of the medial canthus. Of the six patients in the secondary lymphoma group, four had diffuse large B cell lymphoma, one had follicular centre, follicular B cell lymphoma, and one had mantle cell lymphoma (Table 2). According to the working formulation, seven of the MALT lymphomas had previously been classified as small lymphocytic, (diffuse, small, cleaved cell) lymphomas, two were designated as small lymphocytic plasmacytoid lymphoma, and the last as a diffuse, small cleaved cell lymphoma.

Histological examination of the MALT lymphomas revealed a diffuse infiltrate of small cleaved centrocyte-like lymphocytes. A vaguely nodular pattern was seen as a result of follicu- 


\begin{tabular}{|c|c|c|c|c|c|c|c|c|}
\hline Case & $\begin{array}{l}\text { Patient age } \\
\text { (years) }\end{array}$ & Histological type (REAL) & Site of lesion & Presenting complaint & $\begin{array}{l}\text { Symptoms } \\
\text { duration } \\
\text { (months) }\end{array}$ & Initial treatment & $\begin{array}{l}\text { Follow up } \\
\text { (years) }\end{array}$ & Patient outcome \\
\hline \multicolumn{9}{|c|}{ Group 1: Primary ocular adnexal MALT lymphoma } \\
\hline 1 & 35 & MALT lymphoma & Right orbit & Diplopia, proptosis & 1 & $\begin{array}{l}\text { Local excision, } \\
\text { Radiotherapy ( } 25 \text { Gy) }\end{array}$ & 8 & Alive and well \\
\hline 2 & 65 & MALT lymphoma & Left orbit & $\begin{array}{l}\text { Diplopia, pain, } \\
\text { proptosis }\end{array}$ & 3 & $\begin{array}{l}\text { Local excision, } \\
\text { Radiotherapy ( } 28 \text { Gy) }\end{array}$ & 5 & Alive and well \\
\hline 3 & 71 & MALT lymphoma & Left orbit & $\begin{array}{l}\text { Proptosis, soft tissue } \\
\text { swelling }\end{array}$ & 9 & $\begin{array}{l}\text { Local excision, } \\
\text { Radiotherapy ( } 45 \text { Gy) }\end{array}$ & 3 & Alive and well \\
\hline 4 & 50 & MALT lymphoma & Right orbit & Soft tissue swelling & 1 & Local excision & 2 & Alive and well \\
\hline 5 & 45 & MALT lymphoma & Right orbit & Diplopia, proptosis & 4 & Local excision & 2 & Alive and well \\
\hline 6 & 48 & MALT lymphoma & Left lower lid & Palpable mass & Unknown & Local excision & 6 & $\begin{array}{l}\text { Alive and well } \\
\text { (Treated recurrence, } \\
2 \text { years) }\end{array}$ \\
\hline 7 & 72 & MALT lymphoma & Right upper lid & Palpable mass & 12 & Local excision & 5 & $\begin{array}{l}\text { Deceased secondary } \\
\text { other cause }\end{array}$ \\
\hline 8 & 54 & MALT lymphoma & Right conjunctiva & Pain, ptosis & 18 & $\begin{array}{l}\text { Local excision, } \\
\text { Radiotherapy ( } 27 \text { Gy) }\end{array}$ & 4 & $\begin{array}{l}\text { Alive and well } \\
\text { (Treated recurrence, } \\
18 \text { months) }\end{array}$ \\
\hline 9 & 73 & MALT lymphoma & Left conjunctiva & Palpable mass & Unknown & $\begin{array}{l}\text { Local excision, } \\
\text { Radiotherapy ( } 30 \text { Gy) }\end{array}$ & 1 & Alive and well \\
\hline 10 & 48 & MALT lymphoma & Right conjunctiva & Incidental finding & Unknown & $\begin{array}{l}\text { Local excision, } \\
\text { Radiotherapy ( } 30 \text { Gy) }\end{array}$ & 1 & Alive and well \\
\hline \multicolumn{9}{|c|}{ Group 2: Primary ocular adnexal lymphoma of other type } \\
\hline 11 & 62 & Diffuse, large B cell & Left orbit & $\begin{array}{l}\text { Diplopia, soft tissue } \\
\text { swelling }\end{array}$ & Unknown & Chemotherapy (CHOP) & 7 & Alive and well \\
\hline 12 & 75 & Diffuse, large B cell & Right orbit & Proptosis & Unknown & $\begin{array}{l}\text { Radiotherapy ( } 30 \text { Gy), } \\
\text { Chemotherapy (CHOP) }\end{array}$ & 3 & $\begin{array}{l}\text { Deceased secondary } \\
\text { lymphoma }\end{array}$ \\
\hline 13 & 61 & $\begin{array}{l}\text { Follicular centre lymphoma, } \\
\text { follicular }\end{array}$ & Right orbit & Diplopia, proptosis & 2 & Radiotherapy (30 Gy) & 0.5 & Alive and well \\
\hline 14 & 59 & $\begin{array}{l}\text { Peripheral T cell } \\
\text { lymphoma - unspecified }\end{array}$ & $\begin{array}{l}\text { Right medial } \\
\text { canthus }\end{array}$ & Palpable mass & 9 & $\begin{array}{l}\text { Radiotherapy (28 Gy), } \\
\text { Chemotherapy (CHOP) }\end{array}$ & 7 & Alive and well \\
\hline \multicolumn{9}{|c|}{ Group 3: Secondary ocular adnexal lymphoma } \\
\hline 15 & 72 & Diffuse, large B cell & Left orbit & Proptosis, ptosis & 3 & Radiotherapy (25 Gy) & 1 & $\begin{array}{l}\text { Deceased secondary } \\
\text { lymphoma }\end{array}$ \\
\hline 16 & 72 & Diffuse, large B cell & Left orbit & $\begin{array}{l}\text { Proptosis, soft tissue } \\
\text { swelling }\end{array}$ & 2 & $\begin{array}{l}\text { Radiotherapy ( } 30 \mathrm{~Gy}) \text {, } \\
\text { Chemotherapy (CHOP) }\end{array}$ & 1 & $\begin{array}{l}\text { Deceased secondary } \\
\text { lymphoma }\end{array}$ \\
\hline 17 & 78 & Diffuse, large B cell & Left orbit & Pain, proptosis & 2 & Chemotherapy (CHOP) & 1 & Alive and well \\
\hline 18 & 78 & Diffuse, large B cell & Right orbit & Proptosis & 3 & Radiotherapy (25 Gy) & 0.5 & $\begin{array}{l}\text { Deceased secondary } \\
\text { lymphoma }\end{array}$ \\
\hline 19 & 82 & $\begin{array}{l}\text { Follicular centre lymphoma, } \\
\text { follicular }\end{array}$ & Left lower lid & Palpable mass & 6 & Local excision & 0.5 & $\begin{array}{l}\text { Deceased secondary } \\
\text { lymphoma }\end{array}$ \\
\hline 20 & 57 & Mantle cell (B cell) & Right conjunctiva & Pain & 3 & $\begin{array}{l}\text { Chemotherapy (CHOP, } \\
\text { DHAP, cisplatin and } \\
\text { fludarabine) }\end{array}$ & 0.5 & $\begin{array}{l}\text { Deceased secondary } \\
\text { lymphoma }\end{array}$ \\
\hline
\end{tabular}

lar colonisation which is the remnants of pre-existing benign reactive lymphoid follicles overrun by neoplastic small centrocyte-like cells (Fig 1A). Follicle remnants were demonstrated by CD 21 stain which outlined residual dendritic reticular networks in all cases (Fig 1B). The majority of the small cleaved cells were immunoreactive for the B cell marker CD20 and were negative for CD5 and CD10. Small round lymphocytes scattered throughout were immunoreactive for $\mathrm{T}$ cell markers CD3, CD45, and CD5 (Fig 1C). $\mathrm{T}$ cells were also present within the overlying conjunctival epithelium. Other typical features included occasional germinal centres with obvious mantle zones and both multinucleate dendritic cells and plasma cells were prominent in many of the biopsies. The plasma cells consisted both of tumour cells with plasmacytoid differentiation (light chain restricted on immunohistochemistry) and polyclonal plasma cells, which were prominent in two thirds of cases. In three cases with conjunctiva included, lymphoepithelial lesions were seen characterised by lymphocytic invasion of the mucosal surface demonstrated with cytokeratin stain (Fig 1D). Seven of the MALT lymphomas expressed monotypical immunoglobulin, five positive for kappa light chain and two positive for lambda light chain. In three MALT lymphomas assessment of immunoglobulin was not possible owing to technical difficulties and the diagnosis was based on the typical histological findings as outlined above supported by immunostaining demonstrating lesional cells of predominant $\mathrm{B}$ cell origin positive for CD20 but negative for CD5 and CD10.

The diagnosis of the non-MALT lymphomas was based on typical histological features and appropriate expected immunohistochemical findings using the same panel of antibodies and in the case of secondary involvement by previously diagnosed lymphoma, review of and comparison with previous material.

SITE OF LESIONS, PRESENTING SYMPTOMS

The majority of the lymphomas were located in the orbital connective tissues $(n=12)$. There were no lacrimal gland lymphomas. Presenting symptoms were related to the location of the tumour mass within the adnexal tissues (Table 2 ). The most common presenting symptom was proptosis $(n=11)$ and half the patients had more than one presenting symptom. The mean duration between first symptom and presentation was 5.2 months (median 3 months; range 1-18 months) (Table 2).

\section{STAGING OF DISEASE}

Accurate data regarding staging of disease were available in the majority of patients, 18 of 20 . Eight of 10 patients with MALT lymphoma were fully staged and all of these had disease 
confined to the orbit (Table 2). The remaining two patients had localised disease based on clinical evaluation. Among the 10 patients who did not have MALT lymphoma, four were defined as belonging to group 2-that is, primary ocular adnexal lymphoma other than MALT lymphoma, and six as belonging to group 3 (secondary ocular adnexal lymphoma as a manifestation of disseminated disease) (Table 2).

TREATMENT OF DISEASE

All patients with MALT lymphoma had localised treatment with excision of the lesion alone $(\mathrm{n}=4)$ or combined with local radiotherapy in doses ranging from 25 Gy to 46 Gy $(n=6)$ (Table 2). CHOP (cyclophosphamide, doxorubicin, vincristine, and prednisolone) chemotherapy alone or in combination with local radiation (28-30 Gy) was administered to three of the four patients in group 2, two of whom had diffuse large B cell lymphoma, while the third had a peripheral $\mathrm{T}$ cell lymphoma unspecified. The fourth patient with follicular cell, follicular B cell lymphoma had local radiation (30 Gy) (Table 2). The six patients in group 3 with disseminated disease were treated with various modalities and combinations of treatments. Four elderly patients with diffuse B cell lymphoma received either CHOP $(n=2)$ or palliative radiotherapy ( $25 \mathrm{~Gy}, \mathrm{n}=2$ ), while an 82 year old woman with follicular centre, follicular B cell lymphoma was treated with surgical excision only. The sixth patient had disseminated mantle cell lymphoma and was treated with a range of chemotherapies including oral chlorambucil, COP (cyclophosphamide, vincristine, prednisolone), CHOP, DHAP (dexamethasone, cytosine arabinoside, and cisplatin) and cisplatin combined with fludarabine (Table 2).

PATIENT OUTCOME

Those patients with primary ocular adnexal MALT lymphoma had a mean duration of follow up of 3.7 years (median 3.5 years; range 1-8 years), patients in group 2 had a mean follow up of 4.4 years ( 5 years; $0.5-7$ years) and group 3 had a mean follow up of 0.75 years (0.75 years; $0.5-1$ year) The majority of patients with MALT lymphoma are alive $(n=9)$ but one patients has died of an unrelated cause. Two patients with MALT lymphoma had recurrence of disease, one in the gastric mucosa and psoas muscle at 3 years' follow up, and the other in ocular adnexal tissues 2 years after initial treatment. Both patients responded to further treatment (CHOP chemotherapy in the case of gastric mucosa/psoas muscle involvement and local radiation therapy in the patient with adnexal recurrence) Three of the four patients in group 2 are alive and free of disease while one has died of malignant lymphoma. Five of the six patients with disseminated lymphoma have died while one is alive and well following chemotherapy (Table 2).
COMPARISON BETWEEN PATIENT GROUPS A significantly higher proportion of patients with MALT lymphoma initially required local treatment $(p=0.01)$ than patients with other histological types of primary ocular adnexal lymphoma and although a larger proportion of patients with primary MALT lymphoma were alive at last follow up the difference was not significant. A significantly higher proportion of patients with MALT lymphoma presented with local disease $(p=0.005)$, initially required local therapy $(p=0.005)$ and were alive at last follow up $(\mathrm{p}=0.001)$ than patients with all other histological types of lymphoma (both primary and secondary). A higher proportion of patients with all types of primary lymphoma received local treatment than patients with disseminated disease although the difference was not significant but a significantly higher percentage of patients with primary lymphoma (all types) were alive at last follow up ( $\mathrm{p}=$ $0.002)$.

\section{Discussion}

This study has concentrated on patients with malignant ocular adnexal lymphoma, while earlier studies have included patients with histologically benign and indeterminate lymphoid proliferations, ${ }^{20-26}$ which can make comparison of results difficult. Furthermore, few previous papers include MALT lymphoma as a histologically distinct entity. ${ }^{16}$ In this study, immunohistochemistry demonstrated that all of the included cases of ocular adnexal lymphoma except one, were B cell lymphomas. The case in question presented as a localised eyelid tumour which was fully staged and histologically confirmed to be a peripheral $\mathrm{T}$ cell lymphoma unspecified. There has been no evidence of systemic disease on long term follow up. While patients with mycosis fungoides may have involvement of the ocular adnexal tissues, ${ }^{28}$ there is only one previously recorded case of a primary $\mathrm{T}$ cell lymphoma of the ocular adnexal tissues. ${ }^{29}$ The case included in our review supports the view that although rare, primary ocular adnexal lymphomas may be of $\mathrm{T}$ cell type, a fact disputed by previous authors. ${ }^{25}$

Involvement of particular adnexal tissues produces characteristic presenting symptoms and/or clinical signs. The most common presenting symptom was proptosis. This reflected orbital involvement in the majority of patients and all patients with the most frequent combination of symptoms, proptosis, and diplopia also had orbital deposits. In contrast, all patients with lid lesions presented with a palpable mass while those with conjunctival lesions had a variety of presenting complaints. A similar spectrum has been documented in a previous study. ${ }^{17}$ This study, unlike a number of earlier reports did not find a high incidence of conjunctival disease in cases of MALT lymphoma. ${ }^{24}$

While the staging procedures used varied and were not complete in all patients, patients with MALT lymphoma were more likely to have localised disease at presentation. Previous reports disagree as to whether MALT 
lymphoma can occur as primary disease, or as both primary and secondary disease in the ocular adnexa. ${ }^{16}{ }^{17}$ Staging procedures measure the extent of disease and along with histology and performance status determine the treatment approach. Results frequently reflect long term patient outcome. Patients in this study with localised disease and histologically low grade lymphomas received local treatment, an approach similar to that described in previous studies. ${ }^{17}{ }^{25}$ We suggest that all patients with ocular adnexal lymphoma undergo a staging protocol which includes full blood count, differential white cell count, platelet count, full biochemical profile including lactate dehydrogenase levels, bone marrow aspirate, and biopsy with CT scan of head and body. This protocol would normally involve assessment by an oncologist or haematologist.

As in previous studies patients with primary ocular adnexal lymphoma included in this study had a better outcome than those with secondary disease. ${ }^{17}$ 20-22 24-26 Furthermore, when compared with other histological types of lymphoma a significantly higher proportion of MALT lymphoma patients in this study presented with local disease, initially required local treatment, and were alive at last follow up. This is in contrast with a recent study which included MALT lymphoma as a distinct histological type where no significant difference in outcome was seen between MALT lymphoma patients and those with other primary lymphomas. ${ }^{17}$ As evidenced by the two cases reported in this study, all MALT lymphomas have the potential to recur at other MALT sites but the histology at recurrence is generally similar to the initial lesions. ${ }^{14}{ }^{15}$ This tendency is probably due to specific circulation and homing patterns characteristic of lymphocyte subtypes. $^{3031}$ While the number of patients presented here is small, the clinical inference is that the histological recognition of MALT features is important as patients with MALT lymphomas have a more favourable outcome but require indefinite follow up. ${ }^{16}{ }^{17}$

The authors would like to acknowledge the statistical assistance provided by Dr Mary Codd, Department of Epidemiology and Dublin, Republic of Ireland.

1 Nadler LM. The malignant lymphomas. In: Braunwald E, et al, ed. Harrison's principles of internal medicine. 12 th ed. New York: McGraw-Hill, 1991:1599-612.

2 Stansfeld A, Diebold J, Kapanci Y, et al. Updated Kiel classification for lymphomas. Lancet 1988;1:292.

3 Non-Hodgkin's Lymphoma Pathologic Classification Project. National Cancer Institute sponsored study of classifications of non Hodgkin's lymphomas: summary and description of a working formulation for clinical usage. description of a wor
Cancer 1982;49:2112.

4 Freeman C, Berg JW, Cuttler SJ. Occurrence and prognosis of extranodal lymphomas. Cancer 1972;29:252-60.
5 Banfi A, Bondonna G, Carnavali G, et al. Preferential sites of involvement and spread of malignant lymphoma. Eur $\mathcal{f}$ of involvement and spread of malig

6 Harris NL, Jaffe ES, Stein H, et al. A revised EuropeanAmerican classification of lymphoid neoplasms: a proposal from the International Lymphoma Study Group. Blood 1994;84:1361-92.

7 Isaacson PG, Wright DH. Malignant lymphoma of mucosa associated lymphoid tissue. Cancer 1983;52:1410-16.

8 Isaacson PG, Wright DH. Extranodal malignant lymphoma arising from mucosal associated lymphoid tissue. Cancer 1984;53:2524-5.

9 Myhre MJ, Isaacson PG. Primary B cell gastric lymphoma-a reassessment of its histogenesis. F Pathol 1987;152:1-11.

10 Addis BJ, Hyek E, Isaacson PG. Primary pulmonary lymphoma: a reappraisal of its histogenesis and its relationship to pseudolymphoma and lymphoid interstitial pneuship to pseudolymphoma and lymph
monia. Histopathology 1988;13:1-12.

11 Hyek E, Smith WJ, Isaacson PG. Primary B cell lymphoma of salivary glands and its relationship to myoepithelial sialadenitis. Hum Pathol 1988;19:766-76.

12 Hyek E, Isaacson PG. Primary B cell lymphoma of the thyroid and its relationship to Hashimoto's thyroiditis. Hum Pathol 1988;19:1315-26.

13 Wotherspoon AC, Diss TC, Pan LX, et al. Primary low grade B-cell lymphoma of the conjunctiva: a mucosaassociated lymphoid tissue type lymphoma. Histopathology 1993;23:417-24.

$14 \mathrm{Li} \mathrm{G}$, Hansmann ML, Zwingers $\mathrm{T}$, et al. Primary lymphomas of the lung:morphological, immunohistochemical and clinical features. Histopathology 1990;16:519-

15 Isaacson PG. Lymphomas of the mucosa-associated lymphoid tissue (MALT). Histopathology 1990;16:617-19.

16 Jakobiec FA, Iwamoto $\mathrm{T}$, Patell $\mathrm{M}$, et al. Ocular adnexal monoclonal lymphoid tumours with a favourable prognosis. Ophthalmology 1986;93:1547-57.

17 White WL, Ferry JA, Harris NL, Grove AS. Ocular adnexal lymphoma - a clinicopathologic study with identification of lymphomas of mucosa associated lymphoid tissue type. Ophthalmology 1995;102:1994-2006.

18 Bessell EM, Henk JM, Wright JE, et al. Orbital and conjunctival lymphoma treatment and prognosis. Radiother Oncol 1988;13:237-44.

19 Reddy EK, Bhatia P, Evans RG. Primary orbital lymphomas. Int f Radiat Oncol Biol Phys 1988:1239-41.

20 Morgan G, Harry J. Lymphocytic tumours of indeterminate nature: a 5-year follow up of 98 conjunctival and orbital lesions. Br f Ophthalmol 1978;62:381-3.

21 Knowles DM, Jakobiec FA. Orbital lymphoid neoplasms: a clinicopathologic study of 60 patients. Cancer 1980;46: 579-89.

22 Ellis JH, Banks PM, Campbell RJ, et al. Lymphoid tumours of the ocular adnexa. Clinical correlation with the working formulation classification and immunoperoxidase stainin of paraffin sections. Ophthalmology 1985;92:1311-24

23 McNally L, Jakobiec FA, Knowles DM. Clinical, morphological, immunophenotypic and molecular genetic analysis of bilateral ocular adnexal lymphoid neoplasms in 17 patients. Am F Ophthalmol 1987;103:555-68.

24 Medicos LJ, Harris NL. Lymphoid infiltrates of the orbit and conjunctiva: a morphologic and immunophenotypic study of 99 cases. Am f Surg Pathol 1989;13:459-71.

25 Knowles DM, Jakobiec FA, McNally L, et al. Lymphoid hyperplasia and malignant lymphoma occuring in the ocular adnexa (orbit, conjunctiva and eyelids): a prospective multiparametric analysis of 108 cases during 1977 to 1987. Hum Pathol 1990;21:959-73.

26 Jakobiec FA, McLean I, Font R. Clinicopathologic characteristics of orbital lymphoid hyperplasia. Ophthalmology 1979;86:948-66.

27 Hsu SM, Raine L, Fanger H. Use of avidin-biotin peroxidase complex (ABC) in immmunoperoxidase technique:a comparison between $\mathrm{ABC}$ and unlabelled antibody (PAP) procedures. F Histochem Cytochem 1981;29: $577-80$

28 Meekins B, Proia AD, Klintworth GK. Cutaneous T-cell lymphoma presenting as a rapidly enlarging ocular adnexal tumour. Ophthalmology 1985;92:1288-93.

29 Laroche 1, Laroche L, Pavlakis E, et al. Immunological characterisation of an ocular adnexal lymphoid $T$ tumour by monoclonal antibodies. Ophthalmologica 1983;187:43-9.

30 Goudie RB, MacFarlane PS, Lindsay MK. Homing of lymphocytes to non-lymphoid tissues. Lancet 1974;1:292-3.

31 Pals ST, Horst E, Scheper RJ, et al. The mechanisms of human lymphocyte migration and their role in the pathogenesis of disease. Immun Rev 1989;108:111-13. 